\title{
Belgeo
}

Revue belge de géographie

$1 \mid 2021$

Miscellaneous

\section{Implementing Energy-as a Common approach in the revitalization of shrinking cities}

L'énergie comme bien commun dans la revitalisation des villes en déclin

Simone Di Pietro

\section{OpenEdition}

1 Journals

\section{Electronic version}

URL: https://journals.openedition.org/belgeo/49525

DOI: 10.4000/belgeo.49525

ISSN: 2294-9135

\section{Publisher:}

National Committee of Geography of Belgium, Société Royale Belge de Géographie

\section{Electronic reference}

Simone Di Pietro, "Implementing Energy-as a Common approach in the revitalization of shrinking cities", Belgeo [Online], 1 | 2021, Online since 13 July 2021, connection on 24 October 2021. URL: http:// journals.openedition.org/belgeo/49525 ; DOl: https://doi.org/10.4000/belgeo.49525

This text was automatically generated on 24 October 2021

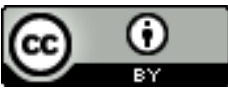

Belgeo est mis à disposition selon les termes de la licence Creative Commons Attribution 4.0 International. 


\title{
Implementing Energy-as a Common approach in the revitalization of shrinking cities
}

L'énergie comme bien commun dans la revitalisation des villes en déclin

\author{
Simone Di Pietro
}

\section{Introduction}

\section{The challenge of greening energy supply in densification demand processes}

1 In the increasingly unstable global context also given by the current COVID-19 pandemic, market-centred development scenarios seem to project civilization towards a fortress world in which elites work to impose an authoritarian order to establish control over resources, where even the concept of sustainability is modelled at will in order to legitimize business as usual (Raskin et al., 2010). In this context of growing uncertainty, the local response acquires greater significance in defining the future of the territories, therefore urban shrinkage contexts already characterized by a certain level of organizational capacity can offer a good ground for innovative development strategies that fit into the postmodern crisis of globalization processes.

2 According to ecological criticism (Martinez Alier, 2002), the economic system is based on the continuous externalization of environmental costs, which are shifted to higher space-time scales and are difficult to quantify. In this context, rural areas are seen with greater potential to return to sustainable development models based on organic production and the use of local resources, while large cities are seen by definition as unsustainable due to too high levels of densification of demand.

3 The world economy is increasingly based on the use of resources found in the environment (Giljum and Eisenmenger, 2004), that are extracted in a heterogeneous 
way on the planet, in turn, creating heterogeneous effects on the availability, quality, demand and supply of energy throughout the world. Considering the physical aspects and in terms of environmental impacts (Schutz et al., 2004), the so-called dematerialization (the use of a lower flow of materials and energy per unit of production) of the economies of the North is carried out, also based on a transfer from the North to the South of the intensive production of natural resources.

On the demand side, higher levels of energy consumption per capita usually correspond to higher GDP per capita (Csereklyeietal, 2016), reflecting the disparities in the development processes, so that, while the biggest concern in northern countries is securing resources to ensure thermal comfort, many global southern countries face extreme energy poverty situations such as a lack of fossil fuel for cooking (Day et al., 2016), especially in rural areas. Another similar issue is the quality of the fuels used, where this is significantly lower in poor countries causing high pollution rates with harmful effects on health.

5 A growing focus on how to solve energy problems is centred in cities, since they already are currently responsible for two thirds of global primary energy demand, and this proportion is growing: considering urbanization processes towards cities with a minimum population of 300,000 inhabitants, in 2050 around $68 \%$ of the world population will be living in cities, compared to the current $55 \%$ (United Nations, 2018). The urbanization process is tightly connected with the heterogenous demographic growth accompanied by the lack of measures in spatial planning: while in countries of low fertility in Europe and Asia, policies of redistribution of the population are promoted, increase in urbanization will be concentrated above all in developing countries, with India, China and Nigeria, which will make the main contribution.

In this context, a sustainable spatial organization of social activities without the use of fossil fuels or nuclear energy requires enormous infrastructure and sociodemographic changes to reduce energy demand and adapt it to the renewable energy resources available in the territory (Ariza-Montobbio et al., 2014). The achievement of these objectives will inevitably have to be based on strong social and structural changes, as well as a substantial re-planning of policies, including redistribution of resources and knowledge-based techniques.

\section{Methodology}

7 This article uses a descriptive approach to discuss the role of shrinking cities within the new geographies produced by economic and energy transitions related to post-Fordist transformations and the advancements in the use of renewable energy sources. The methodology is based on a review of the literature and interviews realised with experts. The work is oriented to provide a theoretical contribution regarding the potential of the energy transition to improve liveability in increasingly marginal urban areas, discussing the possible benefits provided by a local management of energy transitions, through bottom up governance systems driven by principles of energy democracy. 


\section{State of the Art}

\section{Shrinking Cities within the new geographies of post-Fordist and energy transitions}

If the urban society was historically conceived in opposition to the rural society (Castells, 1971), the new transformations given by the arrival of new ruralities on the one hand and shrinking cities on the other, serve to create bridges between the two. Within the dichotomy between rural and urban areas are located shrinking cities, or urban centres progressively marginalized in the economic system and therefore with a possible motivation to undertake new paths aimed at sustainability and endogenous development.

The most recognized definition sees the shrinking city as "a densely populated urban area that has on the one hand faced a population loss in large parts of it (for at least 5 years, more than $0.15 \%$ annually), and is on the other hand undergoing economic transformation with some symptoms of a structural crisis" (Wiechman, 2007).

In the literature, different aspects related to sustainability problems in shrinking cities are emphasized. Whether shrinking cities are associated with more or less carbon emission is inconclusive, empirical evidence shows that shrinking cities tend to be less energy efficient (Liu et al., 2020) and less capable of mitigating $\mathrm{CO}_{2}$ than growing cities (Xiao et al., 2019). The emerging crises in shrinking cities can be seen as opportunities with possible new resources arising (for example vacant spaces) for urban planning aimed at improving liveability and sustainability (Pallagst et al., 2017, 2019).

11 Cases of shrinking cities are described negatively when, rejecting the context of declining population size, sparse urban growth continues to be planned, as in the case of Ostrava in the Czech Republic, where long term unsustainability paths are being created (Slach et al., 2019).

On the other side, approaches to the production of renewable energy or the implementation of more energy-efficient built environment can be implemented in shrinking cities, benefitting themselves of national frameworks, as it is in the cases of Herne (Förch, Pallagst, 2019) and Gelsenkirchen (Jung et al., 2010) in the Coal Mine German Region, and Vitry le François (Béal et al., 2019) in the French region of Marne, whose energy initiatives were applied in the context of the German Energiewende and the French Territoires á energie positive national programs.

13 The environmental problems of shrinking cities are a direct consequence of their increasingly marginal economic situation. Shrinking cities are commonly seen as the sign of a symptom, or the "canary in the coal mine" (Audirac et al., 2010) of the global economic transformations, especially characterised by the post-Fordist transitions. The phenomenon of urban shrinking is considered as a socio-spatial aspect of the global economic system that tends to concentrate capital on the basis of the comparative advantages associated with the territories, modifying the functions for which they are intended. Silverman (2018) adapt the economic theory of dependency to the urban dynamics, where socio-spatial realities of shrinking cities are conceptualized within the economically peripheral regions, so that shrinking cities should be seen as the counterpart to the accumulation of wealth, capital, knowledge and infrastructure in global or metropolitan cities. In this sense, the global-periphery relations between the 
North and the South within the World Economy can be introduced in order to understand the economic relations between global and peripheral cities, where these last are situated in a subordinate situation, representing places of dispossession of the resources necessary to sustain the constant growth in global cities. This situation would be reproduced thanks to a colonized mindset and subconscious processes that would not allow local actors to act in function of a true local endogenous development. In other words, population decline affects not only the hardware, but also the software and mindware of an area, it means beyond the physical infrastructure, the norms and values of local actors, in turn connected to the external representation of their territory (Hospers, 2012). This could be the reason why urban shrinking processes are often treated as a taboo by municipal administrations (Pallagst et al., 2017), evidencing the gap with the academic literature who seeks to interpret this phenomenon as a possibility for planning paradigms, systems, development strategies or alternative cultures (Haase, Rink, 2012). Thus, as in dependency theory, the limited capacity to meet local demand and solve local problems in shrinking cities produces an increased dependence on external resources.

Urban shrinkage understanding as peripheralization process who's also discussed by Lang (2012) in the context of east Germany, is strongly related to flow and capital accumulation that tend to produce temporary "fixes" in space and time (Harvey 2006; Smith, 2010) and geographical inequalities (Großman et al., 2013).

Spatial effects in urban areas are closely linked to the geography of production: in global growth, we observe a glocalization of production driven by leading industries (high technology, aerospace, electronics, financial) that are selectively localized depending on the relative global and regional competitive advantages (Audirac et al., 2012), so that in post Fordist transitions the new industrial production coexist with declining Fordist industrial districts, contributing to the generation of new crises in peripheral spaces. The most important sectors of the "new post-industrial economy" include professional, scientific and technical services, information, finance and insurance, real estate and rentals, arts, entertainment and recreation, business administration, educational services, health care and social assistance (Sassen, 2001). As well as migration and urban shrinkage phenomena increase, especially in countries of the global North, the impact of globalisation on the suburbs of the global South is contributing to the expansion of squatter settlements (Audirac et al., 2012).

Replacing fossil fuels with renewable energies means mobilizing resources closer to consumers, but the potential for exploitation of renewable sources is also heterogeneous, depending on the morphology of the territory, the climatic conditions and the land use applied in it; whereby rural areas are also seen as green energy exporters to meet urban demand. Thus, new relationships arise between rural and urban areas, highlands with potentially more intense renewable energy resources and lowlands, as well as new intermediaries between production and consumption in urban areas (Balaye et al., 2018). This phenomenon is involved in the creation of the so called "new ruralities", rural areas that are assuming the characteristics of urban centres and peri-urban areas conserving rural characteristics.

On the demand side, in recent years, a fairly broad consensus has been established on the importance of promoting urban processes in a logic of compacting settlements, in order to maximize the use of urban land. Planning visions such as polycentric urban form and compact cities are often regarded as ideal-typical urban patterns and 
associated with environmental sustainability; these directives are also presented in the UN Habitat Urban Agenda (2016).

Since the forms of urban settlements have a clear relationship with the use of energy in buildings (Mulligan, 2014), the construction of vertical buildings for multi-family dwellings makes it possible to contain per capita energy consumption, even if this logic supports the dynamics of centralized control in energy generation, by reducing the interurban potential of energy generation and the potential for bottom-up governance.

Different architectural geometries and their positioning affect the use of energy, affecting the potential of passive zones, the implementation of technologies for the production of renewable energy, and contribution to the urban heat islands effect. Maximizing the use of daily light and natural ventilation by increasing the size of the windows or taking advantage of the solar heat thanks to a good positioning of the facades, are some of the measures that contribute to energy efficiency through planning (Mulligan, 2014). In this sense, the reduction of urban densities could have positive effects if the equilibrium point is determined at which it is possible to increase the potential for interurban energy generation in combination with the use of passive areas by new or undergoing building rehabilitation.

With the aim of harmonizing energy demand, the dynamics of urban change must be studied through the analysis of the construction, demolition or adaptation of new buildings, between other, considering large or medium conversion projects for the reuse of abandoned infrastructures. The presence of vacant space or vast low-cost wastelands, could represent key locations for distributed energy generation in shrinking cities. These are usually characterized by the presence of uninhabited or abandoned houses and in some of these cases, demolitions or retrofits of the infrastructure are carried out. The demolitions produce vacant spaces that can then be used for common uses, while, in the case of retrofits, these should be carried out in order to improve energy efficiency, under the concept of passive zones and bio climatic designs.

21 Energy problems in urban declining contexts are discussed by Hornebeck and Schwarz (2009), identifying a strong difference between the declining cities of Europe and North America: being the energy deficit much more pronounced in Europe, it is more likely that policies may redirect towards promoting the distribution of energy demand than in the United States, where, being the energy gaps much less common, cities that have lost population and industries could have a power generation capacity that exceeds demand. In order to cut the costs of maintaining the overcapacity of the energy infrastructure in shrinking cities, Hornebeck and Schwarz (2009) propose three alternatives: eliminating part of the energy infrastructure, reducing the costs of public lighting, and increasing decentralised energy generation systems from renewable sources. More than that, a balance that guarantees efficiency in consumption can be pursued by compacting the settlements, minimizing fragmentation and the use of nonproductive vacant spaces that, if neglected, run the risk of devaluing the rest of the territory (Newman, Kim, 2017). New construction techniques may be implemented considering the concepts of passive areas and deploying potential for distributed renewable energy generation, minimizing the effect of urban heat islands by understanding the desirable levels of urban density according to the climatic characteristics of the territory. The latter can vary considerably depending on the uses of the buildings (housing, commerce, industry, services) and the geographical location 
(for example, temperate or tropical climates). This approach aims to guarantee greater energy efficiency, increasing social interaction and reducing devaluation linked to architectural deterioration. Increasing interactions can have positive effects on improving social capital and increasing organisational capacity, which can in turn bring new innovations of an economic or social nature, given the increased complexity of the urban ecosystem through increased exchanges and contacts (Rueda, 1998).

However, successful interventions will depend on the numerous dynamics resulting from the constant interaction between actors who establish and modify the structure and morphology of settlements (Sánchez, 2013). Uncoordinated processes of compaction of the city run the risk of creating a new dynamic of polarization, inequality (Buhnik, 2017; Fol, 2012) or urban gentrification (Audirac et al., 2012), therefore, municipalities should implement the best urban planning alternatives in order to minimize negative social effects by pursuing a balance between local energy supply and demand.

\section{Discussion and results}

\section{Strategies of energy transition in shrinking cities}

The urban shrinkage phenomenon should be observed as a circular process (Hoekveld, 2012) closely connected with the local context of the region in which it occurs, and the role it plays as a peripheral node into the information network society (Castells, 2004).

The phenomenon of urban shrinking can be very varied and take on different types: Oswalt and Rienits (2007) identified no fewer than twenty-one causes of shrinkage across the world, while Branislav et al. (2019) distinguish the different types of shrinking cities according to the economic-political causes, the character of shrinkage duration, shrinkage timeline, seriousness of shrinkage process, spatial level of shrinkage and size of shrinking city.

Identifying the type of a shrinking city is essential to define the interventions to be applied in view of sustainability. Depending on the type of shrinking city and consequently on the type of resources available, it is possible to identify several strategies that can enable shrinking cities to play an important role in energy transition processes.

These can be summarised into three categories: research and development in green technologies; energy transition plans with an integral approach through public-private partnerships; local energy production through community cooperatives or individual prosumers.

While the first two assume top-down management, the third strategy involves bottomup mechanisms facilitated by the inclusion of appropriate rules.

Technology production strategy is a potentially successful strategy depending on the ability to attract investments to create innovation in highly advanced and competitive sectors.

In Gelsenkirchen, as part of the solar city strategy aimed at redeveloping the image of the city for decades associated with the negative effects of contamination from the coal industry, energy transition is been boosted through the establishment of a Science Park for the research, development and marketing of renewable energies (Jung et al., 2010). 
Despite Science Park Gelsenkirchen has currently lost its role as a photovoltaic technology manufacturing cluster as a result of the German solar industry's lack of competitiveness compared to the efficiency standards achieved by the Asian market ${ }^{1}$, it continues to provide jobs for more than 400 employees engaged in R\&D, marketing and engineering education, through a private public administration, where the ownership shares are divided between the city of Gelsenkirchen and the Gelsenkirchener Gemeinnützige Wohnungsbaugesellschaft $\mathrm{GmbH}$. The experience of Gelsenkirchen demonstrates that the path of renewable energy technology production is difficult to create, especially in shrinking cities such as peripheral areas with low economic diversification, but it can still be a good strategy where there are opportunities to attract a critical mass of skilled workers in the energy industry, especially trained in green technologies. The aim would be to compete in the globalised market with the technologies currently at the forefront of the Asian and North American markets.

Energy transition plans with an integral approach through public-private partnerships is another of the strategies applied in shrinking cities and the degree of transition can be more or less pronounced. Examples include the same city of Gelsenkirchen but also Herne, both of which are located in Westphalia, in the so-called Coal Mine region of Germany. A more industrial ecological approach can be found in the case of Dunkerque in France, but the case that adopts a more advanced integral approach is Vitry le Francois, a shrinking city in the Marne region of France.

31 The cities of Gelsenkirchen and Herne are part of the German Ruhr region in the state of North Rhine Westphalia, being part of the called European Coal Mine region. Both these cities have faced economic transition processes due to the decommissioning of coal mines, deciding to invest in the energy transition aimed at clean energy. In Gelsenkirchen, the "Gelsenkirchen-Bismark Solar Housing Estate" project was completed in 2000s, a real estate project with low energy consumption and solar architecture, for a neighborhood of more than 100 homes (Jung et al., 2010). A very similar project was also established in the nearby city of Herne, where as part of the conversion process of the old mines the Mont-Cenis Energy Park was created, consisting of a cogeneration plant with 3,200 integrated photovoltaic modules, energy storage infrastructure and one of the largest rooftops solar photovoltaic production plants in the world with the power of $1 \mathrm{MW}$, feeding a training academy which acts as a city social centre and district administration of the city of Herne (Förch, Pallagst, 2019).

An industrial ecology approach was adopted in the shrinking city of Dunkerque in France, where a new combined cycle power station with a power capacity of $790 \mathrm{MW}$, replaced the old thermal power station managed by EDF and at the end of its life cycle (Beaurain, Chembessi, 2019).

33 The integral energy transition approach can be found in the shrinking city of Vitry le François. Vitry le François is a town of around 12,000 residents situated in the Champagne region of eastern France. In this formerly industrial area, demographic shrinkage above all concerns the core town of Vitry-le-François, where the population fell by 32\% between 1975 and 2014 (Béal et al., 2019). This process is linked to the strong migration originating from the deindustrialisation typical of the post-Fordist transition and only partially offset by the creation of new jobs in the third sector (Miot, Rousseau, 2017). In particular, from the 1990s a demolition to rebuild strategy is ongoing through an urban renewal project resulting of an agreement between the local administration and the single social landlord «Vitry Habitat», owner of $54 \%$ of housing stock. At the 
same time, a series of 33 projects that include biomass heating system, industrial ecology, renewable energy production, production of hydrogen as a transport fuel, energy efficiency and waste management, are being implemented also thanks to the partnership established with the private sector, in particular with the French energy company Electricité De France (EDF), which can use this territory as an experimental laboratory for future large-scale changes with a view to sustainable development.

Local energy production through community cooperatives or individual prosumers can be seen as a favourable strategy both with a view to achieving energy self-sufficiency and to receive profitable revenues from the sale of surplus energy to the national grid, if the appropriate incentives and legal frameworks are in place. On the other hand, new prosumer business models are emerging in a post-subsidy era (Brown et al., 2019), to compete with fossil fuels and adapt to progressively less generous national subsidy schemes.

According to the REScoop (Renewable Energy Sources Cooperative) network, an increasing number of over 1.900 energy cooperatives are already operating across Europe.

This business scheme, based on the creation of community businesses managed through a horizontal type of governance, seems to be particularly advantageous as a development and community benefit strategy in small and declining towns. Smaller shrinking cities seems to be even more prone to long term and extreme shrinkage (Restrepo et al., 2017), for this reason the system of energy cooperatives can be an alternative way of keeping these centres alive, creating new opportunities for subsistence.

An example of this is the small town of Melpignano, located in the southern area of the region Apulia in Italy, a region characterized by a substantial demographic stability for many years and with projections of a strong demographic decrease of $26 \%$ in the next fifty years, according to the Regional Agency for Technology and Innovation (ARTI, 2019).

Melpignano is one of the small towns in the south of Italy characterized by a nonspecialized primary economy, a poor exploitation of resources and/or potentials, social and economic inactivity, conservative and traditional territorial organization and ways of life: these features are common to a large part of the thick Italian settlement plot, rich in small-sized centers (with less of 5,000 inhabitants), but which are showing a growing openness to local development policies in search of sustainability, looking with hope beyond the decline and change tack, without shutting off from the rest of the world (Rinella, 2019).

Melpignano registered 2.211 inhabitants in 2019, but the demographic trend line shows that, even if temporarily, depopulation occurs in a cyclical way. Regarding the economy, the local system of Melpignano, as well as that of the surrounding municipalities, is classified by ISTAT as "system without specialization". The economy of Melpignano is based on agricultural production for the production of extra virgin olive oil and wine, as well as on tourism generated by the annual event of the final concert of the Taranta music festival, organized every month of August.

The case of Melpignano is one of the emerging energy communities in Italy that are benefiting from national support to renewable energy, which are progressively shaping the Community Energy sector in Italy (Candelise, Ruggieri, 2020). The Melpignano Cooperative Community was created in 2011 by an agreement of 71 founding members 
(then reached 127), under Cooperative Community scheme. Similar to the formula of the Social Cooperative, the Cooperative Community institution is regulated in the Apulian regional law n. 23/2014, with the aim of pursuing the development of the reference community. The initiative was born from the collaboration between Legacoop and the local administration, with the aim of managing a solar energy production network through photovoltaic panels placed on the roofs of public or private buildings. According with his statute, the community cooperative of Melpignano has the responsibility to install the systems and provide for their maintenance, managing the production of energy with metering appropriate to the needs of users and reselling the surplus on the market (Tricarico, 2015). The construction of the decentralised energy system in Melpignano worked thanks to the presence of more extensive building typologies and therefore of numerous roof owners, who transferred their use to the cooperative for 20 years, receiving free energy. The different members of the cooperative join the company voluntarily, based on the different tasks performed: self-employed members, who bring technical skills and take care of the construction of the plants; user members, who are distinguished in "host" members, that is citizens who want to host a photovoltaic system on their roof and "simple" members, who join the project with a membership fee in order to benefit from electricity at favourable conditions; "subsidizing" members, that is those who decide to invest in the project by bringing capital for its realization. The use of profits is established by the shareholders and can be intended for interventions aimed at promoting the regeneration of the urban space: interventions to improve public green areas, refurbishment of road surfaces, school bus services, school canteens. One of the ways to reinvest profits was the installation of a water dispenser in order to supply chilled mineral water at 5 cents per liter, with the aim of generating environmental and economic savings in terms of plastic bottles not produced and of quantities of $\mathrm{CO}_{2}$ not emitted into the atmosphere.

\section{Greening/Rightsizing shrinking cities through energy as a common approach}

41 Referred to the contexts of urban shrinkage, the term 'greening' is used as a strategic approach that aims to develop green infrastructure along with supporting environmentally and socially acceptable practices at the national, state, regional, and local levels (Pallagst et al., 2017). Operating a good greening process should produce convergence between the interests of environmental conservation typically of the national level, with the interests of social and economic benefits at the local level.

While there is a general consensus around the pillar of greening shrinking cities, less emphasis is given to the objectives of regrowing shrinking cities under the consideration that the main objectives should instead be to establish a more liveable, less chaotic urban environment, reducing the stress elements typical of large metropolises. In this sense, the new conditions can be exploited to improve liveability, if considering that size and density are the strongest drivers of unhappiness in the city (Okulicz-Kozaryn, Mazelis, 2018), shrinkage leading to a smaller, less dense environment, should make residents happier (Hartt, 2019). From a theoretical point of view, "the contrary of shrinkage is not growth but adaptability" (Brandstetter et al., 
2005), switching from the slogan "smart growth" to that of "shrink smart" (Pallagst et al., 2009), that is achieved by directing planning towards efficiency and sustainability.

The two pillars of greening and rightsizing shrinking cities can serve as concepts to inspire changes in shrinking cities, where energy transitions with horizontal governance and benefit sharing fall under both of these pillars. The notion of rightsizing should refer to the process of guaranteeing the right to the city for all inhabitants without distinction of any kind; it is therefore closely dependent on the type of new economic opportunities and, in the case of energy transition, on the distribution of benefits at the local level and reinvestment to improve the quality of urban life in shrinking cities. In the absence of this focus that considers advantages and disadvantages on a case-by-case basis, speculative mechanisms could be encouraged, turning out into an attempt to reset growth by converting the most expensive parts of the territorial social economy into a new investment opportunity (Hackworth, 2015). Under bad management or government, interventions of energy transition can be experienced as trojan horses of capitalist accumulation, as is often the case in the global South, where their neo-colonial characterisation often create new socioenvironmental conflicts (Siamanta, Dunlap 2019; Sánchez De Jaegher, 2018). Therefore, the concept of rightsizing is closely linked to that of environmental justice, since the growing interconnectivity has to be recognized between the types of resources (energy, materials, food, water and land), it means between eco and human systems. Energy system has also had a significant role in producing conditions of economic and social inequality (Martinez, 2017), for this reason, energy transition initiatives should be implemented with adequate governance and business models, with the aim of pursuing development that includes environmental justice, since even embracing urban green as a universal amenity may be criticized if traditionally marginalized groups (e.g., low economic class, people of color, low educational attainment) will have less access to amenities and less power in the processes determining their distribution (Schwarz et al., 2018).

Urban greening pillar has gained significance, achieving the status of a tool with strategic urban development potential (Reimer, Othengrafen, \& Rusche, 2015). Greening shrinking cities should primarily focus on the re-use of vacant spaces in order to embrace the new smaller footprints (Pallagst et al., 2017). The rationale behind this practice is that the abandonment of vacant lands reproduces the devaluation of the territory including the properties of the inhabitants, while the re-use of them can constitute a resource for the economic recovery and the revitalization of the territory. According to Newman et al. (2018), land transformation prediction models can be a useful tool for predict spatial vacancies in shrinking cities. Vacant lands represent a shared social responsibility (Dubeaux, Cunningham, 2017) for the community and at the same time a resource, which can be seen as a common good. On the other hand, space has become an important resource to allow a clean energy transition in modern society, due to the low energy intensity of renewable resources compared to fossil fuels. In this sense, a critique to energy transition made by Shellenberger (2019) argues the "poor physics" behind renewable energy sources, so for example "solar farms take 450 times more land than nuclear plants, and wind farms take 700 times more land than natural gas wells, to produce the same amount of energy", would explain that renewable energies are not suitable for the electrification of modern society but rather, would have the aim of transforming back society into agricultural one. However, this criticism does not consider the inherent unsustainability of modern society based on 
the use of fossil fuels, so it is clear that in terms of energy use, a middle way between modern society and agricultural society must be sought from an evolutionary perspective.

This argument leads to deepening the discourse on energy localism and democracy, as a strategy for sustainability and community development. Recognizing the high degree of complexity present in this issue, a holistic and integrated approach must be applied.

Energy Democracy can be understood as a contemporary expression of the political movements of the 1970s and 1980s characterized by anti-nuclear activists and concerns about the geopolitical instability created by the hoarding of fossil fuels (Burke, Stephens, 2018).

Since the crisis of the Fordist model, the local has been rediscovered in the 1970s and 1980s, leading to the emergence of alternative formulas for development, such as: selfdevelopment, eco-development, endogenous development, eco-centric development, integrated development, human-scale development, etc. All these terms refer to the development of local society. Local society is defined as "a human group that inhabits the same territory, shares identity traits and common problems" (Arocena, 1995). The energy democracy movement promotes the transition to a new economic model based on the three main aspects of energy production: its relationship to the environment, social justice and a new economy characterized by community-based development, fair forms of production, socialized capital, ecological use of natural resources and sustainable economic relations (Fairchild, Al Weinrub, 2017). Like governance, sociotechnical systems can be understood as either strengthening or weakening democracy, so that societies face a choice between authoritarian or democratic techniques (Mumford, 1934). In this sense, Hall \& Klitgaard (2012) argue that "When the only energy source harnessed was solar, economic and political power tended to be distributed, whereas, with the introduction of the use of fossil fuels, which are concentrated energy, economic and political powers also became concentrated".

As a low $\mathrm{CO}_{2}$-emitting energy system is the result of the relationship between actors making decisions in a territory composed of natural, technological, economic, legislative, social and cultural systems (Balest et al., 2019), the relationship between actors is fundamental to developing effective energy planning and the inhabitants play a role in the implementation of decentralized energy systems. The collaborative planning approach plays a key role in developing the local civic capacities needed in the adoption of innovative policies. Population size as well as the presence of national environmental networks have strong influence on the adoption of environmental policies to address climate change, and the establishment of climate planning goals are also indicators associated with the adoption of local clean energy policies (Pitt, Basset, 2014).

Citizen participation or civic engagement are intimately linked to the identification of people with their community and consequently with place attachment. They can be a keep factors for shrinking cities: residents who are committed to their community are less likely to move out (Hospers, 2012). Beyond this, ground-up, cooperative and participatory solutions are more sustainable in the long run (Dewar, Thomas, 2013). In the era of globalisation, "the problems of maintenance, production and distribution of the commons in the ecological and socio-economic framework will become increasingly central" (Negri, Hardt, 2009). Despite the problem or "tragedy" (Hardin, 1968) of the commons will always have to deal with free riders and other opportunistic 
behaviors, Ostrom (1975) justifies the choice of cooperation as a strategy to maintain long-term gains.

51 According to several authors, responses to shrinkage must start from the bottom up, embedded in local cultures, institutional configurations and opportunities for change to be effective (Hoekveld, 2012).

This is based on an interdisciplinary approach combining engineering sciences with social and spatial sciences, to jointly build an inclusive territorialisation of the energy transition, leading to energy justice (Henriot et al., 2019).

According to Foldvary (2001), the association of community members for the provision of services, including through the creation of a governmental body, can be conceived as an evolutionary process while the transfer of political authority, property and programs from a higher level to a lower level of governance is to be considered as a devolution process.

Fernández et al. (2014) criticize the permanent delegation and corporatism of modern individualist society, while proposing participatory methodologies as a way to build a new society based on citizen participation, solidarity, co-responsibility and direct democracy, through the integral, multidisciplinary and interdisciplinary action.

Sustainability is not justified by some macro-economic figures, which some experts can give, but by the criteria and indicators of quality of life that each community wants to build at all times, thus marking the pace of their lifestyle (Fernández et al., 2014).

Energy as a common approach must be supported by a technical, social and political aspect. Like all common goods, these must be subject to rules to plan their exploitation. For this reason, communicative planning is an essential aspect. Shrinking cities are laboratories not only for actual urban developments, but for democracy on a local scale (Haase, Rink, 2012). Energy transition that considers renewable energy production as an asset to be managed for community benefits relates co-production with the other levels of service provision: co-governance and co-management (Pestoff, 2012). Cogovernance is about actors from different organizations and sectors coming together to determine policy priorities and to translate these into strategic plans. Co-management refers to a situation where representatives from different organizations work alongside each other to manage the delivery of a service. Co-production is an arrangement where citizens produce, at least in part, the services they use.

\section{Conclusions}

The new European green deal has the objective of achieving climate neutrality by 2050 , implying major new investments in the energy transition sector, with the probable creation of numerous incentives that should be redistributed throughout the territory by the European institutions, as is already happening through DG for Regional and Urban policy, and which could also be used for the revitalisation of shrinking cities.

The adoption of decentralized energy systems is not sufficient by itself to indicate a high degree of energy transition in the urban context. This element must be combined with others, such as the adoption of measures for the efficiency in consumption and policies for the progressive abandonment of fossil fuels. In other words, the degree of energy transition has to do with the analysis of urban metabolism. 
The common characteristics of many shrinking cities such as the overcapacity of energy infrastructure and the presence of vacant spaces can favor energy transitions aimed at reduction in maintenance, transport and production energy costs.

Creating a horizontal governance capable of understanding energy as a common good implies a considerable community effort facilitated by the institutions but put into practice by citizens through models such as the cooperative community of Melpignano.

1 Top down business models linked to energy transitions still prevail, being managed and financed by institutions and implemented through the work of specialized companies such as in the cases of Gelsenkirchen, Herne and Vitry le François. In most cases, the local community benefits from these projects while in others socio-environmental conflicts could arise. Colonized imaginaries may represent obstacles for creating new innovative experiences of local endogenous development through laboratories of democracy in shrinking cities.

Finally, the type of feasible energy transitions in shrinkage cities must be established on various aspects, as the size of cities, current state of the infrastructures, presence of vacant nonproductive spaces, socio-demographic and political characteristics of the population.

The energy cooperative model based on bottom-up rationale is extremely beneficial in the case of small municipalities such as Melpignano, while larger-scale energy transition systems require coordination mechanisms and institutional partnerships in agreement with the greater quantities of investments necessary to convert urban infrastructure.

\section{BIBLIOGRAPHY}

AGENZIA REGIONALE PER LA TECNOLOGIA E L'INNOVAZIONE ARTI-PUGLIA (2019), Andamenti demografici in Puglia. Una sfida per il territorio e per la crescita, Instant Report, https:// www.arti.puglia.it/wp-content/uploads/ARTI-PUGLIA-IT__Instant-report_03-1.pdf

ARIZA-MONTOBBIO P., FARRELL N.K., GAMBOA G. \& RAMOS-MARTIN J. (2014), “Integrating energy and land use planning: socio-metabolic profiles along the urban rural continuum in Catalonia (Spain)", Environment Development and Sustainability, 16, pp. 925- 956.

AROCENA J. (1995), “Centralización y descentralización territorial”, in Desarrollo local, un desafío contemporáneo, Nueva Sociedad, Venezuela.

AUDIRAC I., FOL S. \& MARTINEZ FERNÁNDEZ C. (2010), "Shrinking Cities in a time of crises”, Berkeley Planning Journal, 23, pp. 51-57.

AUDIRAC I., CUNNINGHAM SABOT E., FOL S. \& TORRES MORAES S. (2012), "Declining Suburbs in Europe and Latin America", International Journal of Urban and Regional Research, 36, 2, pp. 226-244.

BALAYE F., BIENVENU L., DEBIZET G. \& LANDEL P. (2018), “Energy Transition: The El Dorado of Urban-Rural Relationships? The Case of Metropolitan and Upland TEPOS Energy Transition: The 
El Dorado of Urban-Rural Relationships? The Case of Metropolitan and Upland", Review of Alpine Research, 106, 2.

BALEST J., SECCO L., PISANI E. \& GAREGNANI G. (2019), “Municipal transitions: The social, energy, and spatial dynamics of sociotechnical change in South Tyrol, Italy", Energy Research \& Social Sciences 54, pp. 211-223.

BÉAL V., FOL S., MIOT Y. \& ROUSSEAU M. (2019), "Varieties of right-sizing strategies: comparing degrowth coalitions in French shrinking cities”, Urban Geography, 40, 2, pp. 192-214, https:// doi.org/10.1080/02723638.2017.1332927

BEAURAIN C., CHEMBESSI C. de R. (2019), «L'écologie industrielle et territoriale : une politique alternative pour la gestion de la décroissance urbaine ? Le cas de Dunkerque », Géographie, Économie, Société, 21, pp. 45-66, https://doi.org/10.3166/ges

BRANDSTETTER B., LAND T. \& PFEIFER A. (2005), “Umgang mit der schrumpfenden Stadt - ein Debattenüberblick", Berliner Debatte Initial, 16, 6, pp. 55-68.

BRANISLAV A., DJUKIC A. \& LOJANICA V. (2019), “The Multiplex Typologies of Shrinking Cities”, $6^{\text {th }}$ international conference on places and technologies, Pecs, Hungary, pp. 100-108.

BROWN D., HALL S. \& DAVIS M.E. (2019), "Prosumers in the post subsidy era: an exploration of new prosumer business models in the UK?", Energy Policy, 135, 110984, https://doi.org/10.1016/ j.enpol.2019.110984

BUHNIK S. (2017), "The dynamics of urban degrowth in Japanese metropolitan areas: what are the outcomes of urban recentralisation strategies?", TPR, 88, 1, pp. 79-92.

BURKE M.J., STEPHENS J.C. (2018), “Political Power and renewable energy futures: a critical review", Energy research \& Social Sciences, 35, pp. 78-93.

CANDELISI C., RUGGIERI G. (2020), "Status and Evolution of the Community Energy Sector in Italy”, Energies, 13, 8, 1888, https://doi.org/10.3390/en13081888

CASTELLS M. (1971), “El mito de la Sociedad urbana”, Revista EURE - Revista de Estudios Urbano Regionales, 1, 3, pp. 27-41.

CASTELLS M. (2004), The Network Society: a cross cultural perspective, Cheltenham, UK Northampton, Mass, Edward Elgar Pub.

CSEREKLYEI Z., RUBIO VARAS Md.M. \& STERN D.I. (2016), "Energy and Economic Growth: The Stylized Facts", The Energy Journal. International Association for Energy Economics, 37, 2.

DAY R., WALKER G. \& SIMCOCK N. (2016), “Conceptualising energy use and energy poverty using a capabilities framework”, Energy Policy, 93, pp. 255-264, https://doi.org/10.1016/j.enpol. 2016.03.019

DEWAR M., THOMAS J.M. (2013), The City After Abandonment, Philadelphia, University of Pennsylvania Press.

DUBEAUX S., CUNNINGHAM SABOT E. (2018), "Maximizing the potential of vacant spaces within shrinking cities, a German approach”, Cities, 75, pp. 6-11, https://doi.org/10.1016/j.cities. 2017.06.015

FAIRCHILD D., AL WEINRUB (2017), Energy Democracy: Advancing Equity in Clean Energy Solutions, Washington, Island Press.

FÉRNANDEZ A., ALBERICH T. \& ARNANZ L. (2014), Fundamentos teóricos y metodológicos. Sociopraxis para la creatividad social, Dextra editorial. 
FOL S. (2012), "Urban Shrinkage and Socio-Spatial Disparities: Are the Remedies Worse than the Disease?, Built Environment, 38, 2, pp. 259-275.

FOLDVARY F.E. (2001), “The Completely Decentralized City: The Case for Benefits Based Public Finance", The American Journal of Economics and Sociology, 60, 1, pp. 403-438.

FÖRCH S., PALLAGST K. (2019), "Energy sector. Energy Park mont-cenis in the city of Herne", in The role of green innovation areas in revitalizing Mexican and German cities, Ibiza, Fondo Editorial Universitario, pp. 146-165.

GILJUM S., EISENMENGER N. (2014), "North-South Trade and the Distribution of Environmental Goods and Burdens: a Biophysical Perspective", The Journal of Environment \& Development, 13, 1, pp. 73-100.

GROßMAN K., BONTJE M., HAASE A. \& MYKHNENKO V. (2013), “Shrinking cities: notes for further research agenda", Cities, 35, pp. 221-225.

HAASE A., RINK D. (2012), "Protest, participation, empowerment, civic engagement in shrinking cities in Europe: the example of housing and neighbourhood development", in HAASE A. (ed.), Shrinking Areas: Front Runners in Innovative Citizen Participation, pp. 29-39.

HACKWORTH J. (2015), "Rightsizing as spatial austerity in the American Rust Belt", Environment and Planning $A, 47,4$, pp. 766-782.

HALL C.A.S., KLITGARD K.A. (2012), Energy and the Wealth of Nations: understanding the biophysical economy, New York, Springer.

HARDIN G. (1968), “The tragedy of the commons”, Science, 162, 3859, pp. 1243-1248.

HARTT M. (2019), "The Prevalence of Prosperous Shrinking Cities", Annals of the American Association of Geographers, 109, pp. 1651-1670.

HARVEY D. (2006), Limits to capital, new and fully updated ed., London, Verso.

HENRIOT C., ARTIS A., MOLINES N., SEIGNEURET N., ANTALUCA E., LAMARQUE F. \& MARTIN E. (2019), The Energy Justice Tool Suite: an interdisciplinary and comprehensive method for energy transition territorialisation, Conference paper "Smart cities and regions informing the energy transition".

HOEKVELD J.J., (2012), “Time-Space Relations and the Differences Between Shrinking Regions”, Built Environment, 38, 2, pp. 179-195.

HOORNEBECK J., SCHWARZ T. (2009), Sustainable Infrastructure in Shrinking Cities, Kent State University.

HOSPERS G.-J. (2012), “Urban shrinkage and the need for civic engagement”, in HAASE A., HOSPERS G.-J., PEKELSMA S. \& RINK D., Rapport Shrinking Areas: Front-Runners in Innovative Citizen Participation.

JUNG W., HARDES A. \& SCHRÖDER W. (2010), “From Industrial Area to Solar Area. The Redevelopment of Brownfields and Old Building Stock with Clean Energy Solutions (City of Gelsenkirchen, Germany)", in Local Governments and Climate Change: Sustainable Energy Planning and Implementation in Small and Medium Sized Communities, pp. 12, Heidelberg, London, New York, Springer - Dordrecht.

LANG T. (2012), "Shrinkage, Metropolization and Peripheralization in East Germany”, European Planning Studies, 20, 10, pp. 1747-1754. 
LIU X., WANG M., QIANG W., WU K. \& WANG X. (2020), “Urban form, shrinking cities, and residential carbon emissions: Evidence from Chinese city-regions”, Applied Energy, 261, August 2019, 114409, https://doi.org/10.1016/j.apenergy.2019.114409

MARTINEZ C. (2017), "From Commodification to the Commons: Charting the Pathway for Energy Democracy", in Energy Democracy Advancing Equity in Clean Energy Solution, Washington, Island Press.

MARTINEZ ALIER J. (2002), "Los indicadores de insustentabilidad urbana como indicadores de conflicto social”, AYER, 46, pp. 43-62.

MIOT Y., ROUSSEAU M. (2019), "Shrinking to Survive? Demolition and Energy Transition in Small-Town France”, Metropolitics, https://metropolitics.org/IMG/pdf/met-miot-rousseaueng.pdf

MULLIGAN H. (2014), "Environmental Sustainability Issues for Shrinking Cities: US and Europe", in PALLAGST K., WIECHMANN T. \& MARTINEZ-FERNANDEZ C. (eds.), Shrinking Cities, International Perspectives and Policy Implications, Routledge, Abingdon, UK, pp. 279-302.

MUMFORD L. (1934), Technics and Civilization, New York, Harcourt, Brace and Co.

NEGRI A., HARDT M. (2009), Commonwealth, Cambridge, Harvard University Press.

NEWMAN G., KIM B. (2017), "Urban shrapnel: spatial distribution of non-productive space”, Landscape Research, doi:10.1080/01426397.2017.1363877.

OKULICZ-KOZARYN A., MAZELIS M. (2018), “Urbanism and happiness: A test of Wirth's theory of urban life", Urban Studies 55, 2, pp. 350-364.

OSTROM E., OSTROM V. (1975), "Public Goods and Public Choices", in SAVAS S. (ed.), Alternatives for Delivering Public Services, Boulder, Colo., Westview Press, pp. 7-49.

OSWALT P., RIENIETS T. (2007), Global context, shrinking cities, http://www.shrinkingcities.com/ fileadmin/shrink/downloads/pdfs/Shrinking_Cities_Project.pdf

PALLAGST K., SCHWARZ T., POPPER F.J. \& HOLLANDER J.B. (2009), “Planning shrinking cities”, Progress in Planning, 72, 4, pp. 223-232.

PALLAGST K., FLESCHURZ R. \& TRAPP F. (2017), “Greening the shrinking city - policies and planning approaches in the USA with the example of Flint, Michigan" Landscape Research, 42, 7.

PALLAGST K., VARGAS-HERNÁNDEZ J. \& HAMMER P. (2019), “Green Innovation Areas - En Route to Sustainability for Shrinking Cities?”, Sustainability, 11, 23, 6674, https://doi.org/10.3390/ su11236674

PESTOFF V.A. (2012), "New public governance, co-production and the third sector: crowding in and crowding out", in New Public Governance, Co-Production and the Third Sector, London, Routledge, pp. 361-380.

PITT D., BASSET E. (2014), "Innovation and the Role of Collaborative Planning in Local Clean Energy Policy”, Environmental Policy and Governance, 26, pp. 377-390.

RASKIN P.D., ELECTRIS C. \& ROSEN R.A. (2010), “The Century Ahead: Searching for Sustainability”, Sustainability, 2, pp. 2626-2651.

REIMER M., OTHENGRAFEN F. \& RUSCHE K. (2015), “Grüne Infrastruktur in urbanen Räumen”, RaumPlanung, 4, pp. 6-7.

RESTREPO C.P., CINEAS G., QUINTERO L. \& ZHUKOVA S. (2017), Cities in Eastern Europe and Central Asia: A Story of Urban Growth and Declinen, Washington, DC, World Bank. 
RINELLA A. (2019), “The Italian outstanding dilemma between fossil stocks and renewable resources: two Apulian case studies", Central European Journal of Geography and Sustainable Development, 1, 2, pp. 53-64.

RUEDA S. (1998), “La ciudad compacta y diversa frente a la conurbación difusa”, in Biblioteca: Ciudades para un futuro más sostenible. Primer catálogo español de buenas práctica, Madrid, Ministerio de Obras Publicas, Transportes y Medio Ambiente, http://habitat.aq.upm.es/cs/p2/a009.html

SÁNCHEZ R. (2013), “Las dinámicas urbanas”, Revista de geografía Norte Grande, 56, pp. 5-6, https:// dx.doi.org/10.4067/S0718-34022013000300001

SÁNCHEZ DE JAEGHER C. (2018), "Saving the planet with green capitalism? Or re-signifying our existence with Mother Earth? The Mapuche-Valdivian case against the wind farm Pililín in the South of Chile", Forum for inter-american research (FIAR), 11, 3, pp. 32-46.

SASSEN S. (2001), The Global City. New York, London, Tokyo, Princeton, New Jersey/Woodstock, Oxfordshire, Princeton University Press.

SCHUTZ H., MOLL S. \& BRINGEZU S. (2004), Globalization and the Shifting of Environmental Burden. Material Trade Flows of the European Union, Wuppertal Institute, Germany.

SCHWARZ K., BERLAND A. \& HERRMANN D.L. (2018), “Green, but not just? Rethinking environmental justice indicators in shrinking cities", Sustainable Cities and Society, 41, pp. 816-821, https://doi.org/10.1016/j.scs.2018.06.026

SHELLENBERGER M. (2019), The reason renewables can't power modern civilization is because they were never meant to, Forbes, https://www.forbes.com/sites/michaelshellenberger/2019/05/06/thereason-renewables-cant-power-modern-civilization-is-because-they-were-never-meant-to/

SIAMANTA Z., DUNLAP A. (2019), “Accumulation by Wind Energy”, ACME: An International Journal for Critical Geographies, 18, 4, pp. 925-955, https://acme-journal.org/index.php/acme/article/view/ 1718

SILVERMAN R.M. (2018), "Rethinking shrinking cities: Peripheral dual cities have arrived", Journal of Urban Affairs, 42, pp. 294-311.

SLACH O., BOSÁK V., KRTIČKA L., NOVÁČEK A. \& RUMPEL P. (2019), “Urban Shrinkage and Sustainability : Assessing the Nexus between Population Density, Urban Structures and Urban Sustainability", Sustainability, 11, 4142, doi:10.3390/su11154142.

SMITH N. (2010) (3 $3^{\text {rd }}$ ed.), Uneven Development: Nature, Capital and the production of space, London, Verso.

TRICARICO L. (2015), “Energia come community asset e orizzonte di sviluppo per le imprese di comunità", Impresa Sociale, 5, pp. 53-64.

UNITED NATIONS (2016), "La nueva agenda urbana", in Conferencia Habitat III.

UNITED NATIONS (2018), Las ciudades seguirán creciendo, sobre todo en los países en desarrollo. Departamento de Asuntos Económicos y Sociales, https://www.un.org/development/desa/es/news/ population/2018-world-urbanization-prospects.html

XIAO H., DUAN Z., ZHOU Y., ZHANG N., SHAN Y., LIN X. \& LIU G. (2019), “CO 2 emission patterns in shrinking and growing cities: A case study of Northeast China and the Yangtze River Delta", Applied Energy, 251, January, 113384, https://doi.org/10.1016/j.apenergy.2019.113384

WIECHMANN T. (2007), "What are the problems of shrinking cities? Lessons learned from an international comparison", in The future of shrinking cities - Problems, patterns and strategies of urban transformation in a global context, Berkeley, CA, Studies, Center for Global Metropolitan 
Development, Institute of Urban and Regional Network, and the Shrinking Cities International Research, pp. 5-16.

\section{NOTES}

1. Interview with Projektmanager Wissenschaftspark Gelsenkirchen $\mathrm{GmbH}$, October $14^{\text {th }}, 2020$.

\section{ABSTRACTS}

The new attempts to implement green transformations of the economy aimed at sustainability coexist with the passage from the Fordist to the post-Fordist era, contributing to create profound territorial transformations throughout the world. Although the current economic crisis is slowing the process of energy transition at the global level, the definition of the future economic structure of territories will be strictly connected to the spatial effects of energy transitions and their intensive land use processes, given the low-power nature of renewable energy sources. Urban centres are the places where these changes are reflected most quickly and clearly, being the centres of major economic activities. In this regard, urban areas experiencing progressive economic marginalisation with consequent depopulation, face sustainability issues regarding energy use and maintenance of the existing infrastructure. With the aim of clarifying the role of shrinking cities within these transformations, a theoretical contribution is presented considering different approaches to co-production of energy transition processes in them.

Les nouvelles tentatives de mise en œuvre de transformations vertes de l'économie visant la durabilité coexistent avec le passage de l'ère fordiste à l'ère post-fordiste, contribuant à créer de profondes transformations territoriales dans le monde entier. Bien que la crise économique actuelle ralentisse le processus de transition énergétique au niveau mondial, la définition de la future structure économique des territoires sera strictement liée aux effets spatiaux des transitions énergétiques et à leurs processus intensifs d'utilisation des sols, étant donné la faible puissance des sources d'énergie renouvelables. Les centres urbains sont les lieux où ces changements se reflètent le plus rapidement et le plus clairement, car ils sont les centres des principales activités économiques. À cet égard, les zones urbaines qui connaissent une marginalisation économique progressive et une dépopulation conséquente, sont confrontées à des problèmes de durabilité concernant l'utilisation de l'énergie et la maintenance des infrastructures existantes. Dans le but de clarifier le rôle des villes en décroissance dans ces transformations, une contribution théorique est présentée en considérant différentes approches de la co-production des processus de transition énergétique dans ces villes.

\section{INDEX}

Mots-clés: villes en décroissance, production d'énergie décentralisée, bien commun, planification collaborative, énergies renouvelables, développement territorial

Keywords: shrinking cities, decentralized energy production, energy-as common, collaborative planning, renewable energies, territorial development 
AUTHOR

\section{SIMONE DI PIETRO}

Technische Universität Kaiserslautern, Department of Spatial and Environmental Planning, Early Stage Researcher in RE-CITY ITN, MCSAction agreement 813803, dipietro@rhrk.uni-kl.de 